A C T A C H E M I A S C A N D I N A V I C A 8 (1954) $1513-1.518$

\title{
A Microscopic Investigation of Binary Systems of Long Normal and Iso-Chain Carboxylic Acids
}

\author{
ERIK VOn SYDOW
}

Institute of Chemistry, University of Uppsala, Uppsala, Sweden

\begin{abstract}
Tn this paper stearic acid is called $n-\mathrm{C}_{18}, i s o$-palmitic acid iso- $\mathrm{C}_{16}$ and so on. Mixtures of long normal and iso-chain carboxylic acids are of great biological importance and they may also have analytical use.

As a way of identifying long iso-chain carboxylic acids Weitkamp ${ }^{1}$ suggested the study of binary systems between the unknown iso-fatty acid and different normal fatty acids. He found that iso- $\mathrm{C}_{18}$ gave a simple eutectic mixture with $n-\mathrm{C}_{17}$ but an incongruently melting molecular compound with $n-\mathrm{C}_{16}$, and that $i s o-\mathrm{C}_{20}$ gave the same types of systems with $n-\mathrm{C}_{19}$ and $n-\mathrm{C}_{18}$, respectively. He suggests that iso-fatty acids give molecular compounds with normal fatty acids which have two carbon atoms less than the iso-acid. He also makes a schematic explanation of this behaviour.

In order to locate a methyl group in a methyl substituted fatty acid Cason and Winans ${ }^{2}$ studied the binary systems with normal fatty acids. A part of their paper deals with the systems of $i s o-\mathrm{C}_{18}$ with $n-\mathrm{C}_{17}$ and $n-\mathrm{C}_{16}$. The results are almost the same as those of Weitkamp ${ }^{1}$.

In this investigation many more systems of iso- and normal fatty acids have been investigated. Iso-acids with 14, 15, 16, 17, 18, 20, 25, and 26 carbon atoms have been studied. The contact method described by Kofler and Kofler ${ }^{3 . p .115}$ has been used. This method is much faster than the ordinary capillary method, but on the other hand it does not give the compositions of the eutectic points and the molecular compounds. This is not fundamental, however, at the first mapping of the binary systems of iso- and normal chain carboxylic acids.
\end{abstract}

\section{MATERIAL USED}

All acids used were obtained from Professor E. Stenhagen and his collaborators. The $i s o$-acids are described in Refs. ${ }^{4-6}$ and the normal acids in Refs. ${ }^{7-9}$.

Normal fatty acids exhibit polymorphism ${ }^{9}$. From melt the even-numbered acids crystallize in form $\mathrm{C}$ which has been investigated by Vand, Morley, and Lomer ${ }^{10}$. The unit cell is monoclinic and the crystal form has the orthorhombic 
Table 1. Thermal data for binary systems of long normal- and is o-chain

\begin{tabular}{|c|c|c|c|c|c|c|c|c|}
\hline $\begin{array}{c}\text { Number } \\
\text { of carbon } \\
\text { atoms in } \\
\text { the iso- } \\
\text { acid }\end{array}$ & $\begin{array}{l}\text { M. p. } \\
\text { of } \\
\text { iso- } \\
\text { acid } \\
{ }^{\circ} \mathrm{C}\end{array}$ & $\begin{array}{c}\text { Eutectic } \\
\text { point } \\
{ }^{\circ} \mathrm{C}\end{array}$ & $\begin{array}{c}\text { Incongruent } \\
\text { m. p. of } \\
\text { molecular } \\
\text { compound } \\
{ }^{\circ} \mathrm{C}\end{array}$ & $\begin{array}{l}\text { Congruent } \\
\text { m.p. of } \\
\text { molecular } \\
\text { compound } \\
{ }^{\circ} \mathrm{C}\end{array}$ & $\begin{array}{c}\begin{array}{c}\text { Eutectic } \\
\text { point }\end{array} \\
{ }^{\circ} \mathrm{C}\end{array}$ & $\begin{array}{l}\text { M. p. } \\
\text { of } \\
n- \\
\text { acid } \\
{ }^{\circ} \mathrm{C}\end{array}$ & $\begin{array}{c}\text { Number } \\
\text { of carbon } \\
\text { atoms in } \\
\text { the } n- \\
\text { acid }\end{array}$ & $\begin{array}{c}\text { Type } \\
\text { in } \\
\text { Table } \\
2\end{array}$ \\
\hline 14 & $\begin{array}{l}\mathbf{5 3} \\
53 \\
\mathbf{5 3} \\
\mathbf{5 3}\end{array}$ & $\begin{array}{l}31 \\
39 \\
39 \\
37\end{array}$ & \multirow{4}{*}{. } & & & $\begin{array}{l}44 \\
41 \\
54 \\
52\end{array}$ & $\begin{array}{l}12 \\
13 \\
14 \\
15\end{array}$ & $\begin{array}{l}\mathbf{E} \\
\mathbf{E} \\
\mathbf{E} \\
\mathbf{E}\end{array}$ \\
\hline 15 & $\begin{array}{l}\mathbf{5 2} \\
52 \\
52 \\
52 \\
52\end{array}$ & $\begin{array}{l}32 \\
40 \\
47 \\
44 \\
39\end{array}$ & & & & $\begin{array}{l}44 \\
41 \\
54 \\
52 \\
63\end{array}$ & $\begin{array}{l}12 \\
13 \\
14 \\
15 \\
16\end{array}$ & $\begin{array}{l}\mathbf{E} \\
\mathbf{E} \\
\mathbf{E} \\
\mathbf{E} \\
\mathbf{E}\end{array}$ \\
\hline 16 & $\begin{array}{l}62 \\
62 \\
62 \\
62\end{array}$ & $\begin{array}{l}31 \\
34 \\
42 \\
49\end{array}$ & & & & $\begin{array}{l}44 \\
41 \\
54 \\
52\end{array}$ & $\begin{array}{l}12 \\
13 \\
14 \\
15\end{array}$ & $\begin{array}{l}\mathbf{E M} \\
\mathbf{E} \\
\mathbf{E M} \\
\mathbf{E}\end{array}$ \\
\hline 17 & $\begin{array}{l}60 \\
60 \\
60 \\
60 \\
60 \\
60 \\
60\end{array}$ & $\begin{array}{l}\mathbf{3 4} \\
\mathbf{3 7} \\
\mathbf{4 3} \\
\mathbf{5 0 . 5} \\
\mathbf{5 5} \\
\mathbf{5 3} \\
\mathbf{4 8}\end{array}$ & & $\begin{array}{l}38 \\
44 \\
52\end{array}$ & $\begin{array}{l}34 \\
43 \\
51\end{array}$ & $\begin{array}{l}\mathbf{4 4} \\
41 \\
54 \\
52 \\
63 \\
61 \\
70\end{array}$ & $\begin{array}{l}12 \\
13 \\
14 \\
15 \\
16 \\
17 \\
18\end{array}$ & $\begin{array}{l}\mathbf{E} \\
\mathbf{M} \\
\mathbf{M} \\
\mathbf{M} \\
\mathbf{E} \\
\mathbf{E} \\
\mathbf{E}\end{array}$ \\
\hline
\end{tabular}

packing of the hydrocarbon chains described by Bunn ${ }^{11}$ and Vainshtein and Pinsker ${ }^{12}$. In this packing the plane of every second chain is almost perpendicular to the plane of the others. The odd-numbered normal fatty acids crystallize from melt in form $\mathrm{B}^{\prime}$, except $n$ - $\mathrm{C}_{13}$ which gives crystal form $\mathrm{A}^{\prime}$. Form $A^{\prime}$ is described by the author ${ }^{13}$. The unit cell is triclinic and the crystal form has the triclinic packing of hydrocarbon chains described by Müller and Lonsdale ${ }^{14}$. In this packing all the chain planes are parallell. Form $B^{\prime}$ has been investigated by the author and will soon be described. It has a triclinic unit cell and the same orthorhombic packing as form $\mathrm{C}$ of even-numbered acids.

The iso-acids used in this investigation seem to appear in only one crystal form ${ }^{5}$. Iso-palmitic acid has been investigated by Stenhagen, Vand and Sim ${ }^{15}$.

It is well known that mixing two compounds may cause a change of crystal for $m$ of one or both components, and this may of course be possible here as well.

\section{THERMAL STUDIES}

The binary systems were studied in a polarizing microscope using a heating arrangement ("Heiztisch") designed by Kofler and Kofler 3, p. 2. The contact method described by the same authors ${ }^{3, \text { p. } 115}$ was used. According to this 
carboxylic acids measured on the "Heiztisch" by Kofler and Kofler ${ }^{3}$.

\begin{tabular}{|c|c|c|c|c|c|c|c|c|}
\hline $\begin{array}{c}\text { Number } \\
\text { of carbon } \\
\text { atoms in } \\
\text { the iso- } \\
\text { acid }\end{array}$ & $\begin{array}{l}\text { M. p. } \\
\text { of } \\
\text { iso- } \\
\text { acid } \\
{ }^{\circ} \mathrm{C}\end{array}$ & $\begin{array}{c}\text { Eutectic } \\
\text { point } \\
\\
{ }^{\circ} \mathrm{C}\end{array}$ & $\begin{array}{c}\text { Incongruent } \\
\text { m. p. of } \\
\text { molecular } \\
\text { compound } \\
{ }^{\circ} \mathrm{C}\end{array}$ & $\begin{array}{c}\text { Congruent } \\
\text { m. p. of } \\
\text { molecular } \\
\text { compound } \\
{ }^{\circ} \mathrm{C}\end{array}$ & $\begin{array}{c}\text { Eutectic } \\
\text { point } \\
{ }^{\circ} \mathrm{C}\end{array}$ & $\begin{array}{l}\text { M. p. } \\
\text { of } \\
n- \\
\text { acid } \\
{ }^{\circ} \mathrm{C}\end{array}$ & $\begin{array}{c}\text { Number } \\
\text { of carbon } \\
\text { atoms in } \\
\text { the } n- \\
\text { acid }\end{array}$ & $\begin{array}{c}\text { Type } \\
\text { in } \\
\text { Table } \\
2\end{array}$ \\
\hline 18 & $\begin{array}{l}68 \\
68 \\
68 \\
68 \\
68\end{array}$ & $\begin{array}{l}32 \\
42 \\
45.5 \\
50.5 \text { a } \\
55 \text { c }\end{array}$ & $\begin{array}{l}43.5 \\
52 \mathrm{~b}\end{array}$ & & & $\begin{array}{l}41 \\
54 \\
52 \\
63 \\
61\end{array}$ & $\begin{array}{l}13 \\
14 \\
15 \\
16 \\
17\end{array}$ & $\begin{array}{l}\mathbf{E} \\
\mathbf{E M} \\
\mathbf{E} \\
\mathbf{E M} \\
\mathbf{E}\end{array}$ \\
\hline 20 & $\begin{array}{l}74 \\
74 \\
74 \\
74 \\
74 \\
74\end{array}$ & $\begin{array}{l}44 \\
\\
52 \\
54 \\
59 \mathrm{~d} \\
64 \mathrm{f}\end{array}$ & 46.5 & $\begin{array}{l}53 \\
55\end{array}$ & $\begin{array}{l}44.5 \\
52 \\
52.5\end{array}$ & $\begin{array}{l}\mathbf{5 4} \\
\mathbf{5 2} \\
\mathbf{6 3} \\
\mathbf{6 1} \\
70 \\
\mathbf{6 9}\end{array}$ & $\begin{array}{l}14 \\
15 \\
16 \\
17 \\
18 \\
19\end{array}$ & $\begin{array}{l}\mathrm{E} \\
\mathrm{ME} \\
\mathrm{M} \\
\mathbf{M} \\
\mathrm{EM} \\
\mathrm{E}\end{array}$ \\
\hline 25 & $\begin{array}{l}82 \\
82 \\
82 \\
82 \\
82 \\
82 \\
82 \\
82\end{array}$ & $\begin{array}{l}60 \\
68.5 \\
73.5 \\
71 \\
78 \\
77 \\
75\end{array}$ & 78.5 & $\begin{array}{l}69 \\
75 \\
73\end{array}$ & $\begin{array}{l}62 \\
68 \\
73 \\
72.5\end{array}$ & $\begin{array}{l}70 \\
69 \\
75 \\
74 \\
80 \\
79 \\
84 \\
83\end{array}$ & $\begin{array}{l}18 \\
19 \\
20 \\
21 \\
22 \\
23 \\
24 \\
25\end{array}$ & $\begin{array}{l}\mathbf{E} \\
\mathbf{M E} \\
\mathbf{M} \\
\mathbf{M} \\
\mathbf{M} \\
\mathbf{E M} \\
\mathbf{E} \\
\mathbf{E}\end{array}$ \\
\hline 26 & $\begin{array}{l}87 \\
87 \\
87 \\
87 \\
87 \\
87 \\
87\end{array}$ & $\begin{array}{l}62 \\
\\
68 \\
70 \\
73 \\
75 \\
80\end{array}$ & 76.5 & $\begin{array}{l}69 \\
73 \\
74.5\end{array}$ & $\begin{array}{l}67 \\
67 \\
71.5 \\
73\end{array}$ & $\begin{array}{l}69 \\
75 \\
74 \\
80 \\
79 \\
84 \\
83\end{array}$ & $\begin{array}{l}19 \\
20 \\
21 \\
22 \\
23 \\
24 \\
25\end{array}$ & $\begin{array}{l}\mathrm{E} \\
\mathrm{ME} \\
\mathbf{M} \\
\mathbf{M} \\
\mathbf{M} \\
\mathbf{E M} \\
\mathrm{E}\end{array}$ \\
\hline
\end{tabular}

a) Weitkamp ${ }^{1}: 52^{\circ}$

b) Weitkamp ${ }^{1}: 53^{\circ}$

c) Weitkamp $1: 58^{\circ}$

d) Weitkamp': $60.5^{\circ}$

e) Weitkamp1: $59.5^{\circ}$

f) Weitkamp1: $65^{\circ}$

method the components are melted on an objectglass under a coverslip so that a contact is formed. They are then allowed to diffuse into each other so that the concentration of the components varies continuously from 0 to $100 \%$. The whole melt is then cooled down and then gently heated on the "Heiztisch" under the microscope. Then the melting parts will appear as black zones, which grow wider and wider. The thermometer was calibrated with the normal fatty acids used, the melting points of which were known accurately ${ }^{7-9}$. For further details of the "Heiztisch" and the contact method Kofler and Kofler 3 should be consulted. 
Table 2. Types of binary systems of long normal-and is o-chain carboxylic acids.

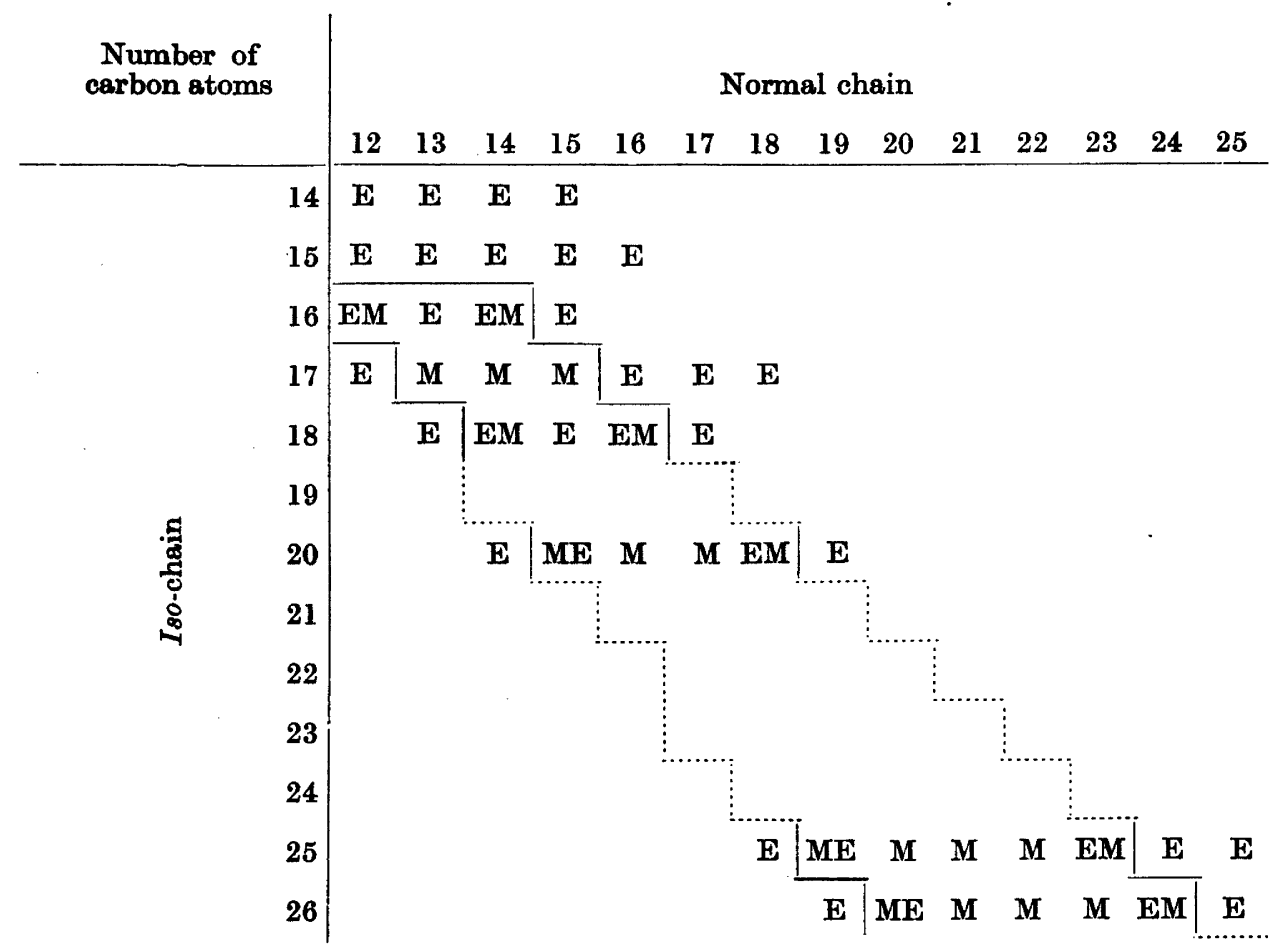

$\mathbf{E}=$ eutectic mixture

$\mathbf{E M}=$ incongruently melting molecular compound with eutecticum between itself and the iso-acid.

ME = incongruently melting molecular compound with eutecticum between itself and the $n$-acid.

M = congruently melting molecular compound.

Three different types of binary systems were obtained: the components forming eutectic mixtures, congruently melting compounds and incongruently melting compounds. Alla data obtained are collected in Tables 1 and 2.

\section{DISCUSSION OF RESULTS}

As Weitkamp ${ }^{1}$ pointed out iso-acids form molecular compounds with normal acids, which have two carbon atoms less. However, when the iso-acid has 15 of fewer carbon atoms no molecular compounds are obtained (see Table 2). This is probably due to stabilization of the different structure types of the components caused by the comparatively great influence of the carboxylic groups when the chains are short. 
For the higher iso-acids molecular compounds are obtained with normal acids having two or more carbon atoms less than the iso-acid. Thus iso- $\mathrm{C}_{17}$ forms three molecular compounds and $i s o-\mathrm{C}_{26}$ five (see Table 2). The schematic explanation by Weitkamp ${ }^{1}$ for systems $i s o-\mathrm{C}_{n}-n-\mathrm{C}_{\mathrm{n}-2}$ is very informative, whether the packing of the hydrocarbon chains is of the orthorhombic, triclinic or perhaps another type. When the difference is three or more carbon atoms there will probably be holes in the packing and when these holes are too large the molecular compound will collapse. Of course when the number of carbon atoms in the $i s o$-acid increases the largest allowable size of the holes will also increase.

For the shortest even-numbered iso-acids and the possible normal acids, the influence of the carboxylic groups on the structure types is still too great so that in some cases no molecular compound is obtained. A regular behaviour does not appear until iso- $\mathrm{C}_{20}$.

It is known that if a binary system contains an intermediate phase this often forms a peritectic if the difference between the melting points of the compounds is large. Then the eutectic lies between the intermediate phase and the component with the lowest melting point. The results now obtained show a tendency in this direction for iso- $\mathrm{C}_{20}$ and longer acids. The system iso- $\mathrm{C}_{20}$ $-n-\mathrm{C}_{15}$ is of the type ME, i.e. the eutectic lies between the intermediate phase and the phase with the lowest melting point. When the length and the melting point of the $n$-acid increases the type changes to $M$ and later to EM.

\section{SUMMARY}

Binary systems of long normal and iso-chain carboxylic acids are studied under the microscope. Iso-acids with $14,15,16,17,18,20,25$, and 26 carbon atoms have been investigated. Those with 16 or more carbon atoms are found fo form molecular compounds with normal acids having two to four, five or six carbon atoms less than the iso-acid. Some anomalies in the binary systems for the lower members of the iso-acids have been found.

Acknowledgement. I am indebted to Professors Gunnar Hägg and Einar Stenhagen for valuable discussions and for their interest.

\section{REFERENCES}

1. Weitkamp, A. W. J. Am. Chem. Soc. 67 (1945) 447.

2. Cason, J. and Winans, W. R. J. Org. Chem. 15 (1950) 148.

3. Kofler, L. and Kofler, A. Mikromethoden zur Kennzeichnung organischer Stoffe und Stoffgemische, Innsbruck 1948.

4. Stenhagen, E. and Tägtström, B. Arkiv Kemi, Mineral. Geol. 19 A (1944) No. 8.

5. Arosenius, K. E., Ställberg, G., Stenhagen, E. and Tägtström-Eketorp, B. Ibid. 26 A (1948) No. 19.

6. Stenhagen, E. Private communication.

7. Ställberg-Stenhagen, S. Arkiv Kemi, Mineral. Geol. 20 A (1945) No. 19.

8. Ställberg-Stenhagen, S. and Stenhagen E. Ibid. 19 A (1944) No. 1.

9. Stenhagen, E. and von Sydow, E. Arkiv Kemi 6 (1953) 309.

Acta Chem. Scand. 8 (1954) No. 9 
10. Vand, V., Morley, W. M. and Lomer, T. R. Acta Cryst. 4 (1951) 324.

11. Bunn, C. W. Trans. Faraday Soc. 35 (1939) 482.

12. Vainshtein, B. K. and Pinsker, Z. G. Doklady Akad. Nauk. SSSR. 72 (1950) 53.

13. von Sydow, E. Acta Cryst. 7 (1954) 529.

14. Müller, A. and Lonsdale, K. Ibid. 1 (1948) 129.

15. Stenhagen, E., Vand, V. and Sim. A. Ibid. 5 (1952) 695.

Received June 14, 1954. 